\title{
Business Information Utilization for Sustainable Entrepreneurial Knowledge among SMEs in Lagos Metropolis
}

\author{
${ }^{1}$ Adesanya, A.S. \& ${ }^{2}$ Adewumi, D.O. \\ 1Department of Business Administration and management \\ 2Department of Office Technology and Management \\ Lagos State Polytechnic \\ Ikorodu, Lagos, Nigeria \\ E-mail: asetaded2nd62@gmail.com; adewumi_damisola2000@gmail.com \\ Phone: +234 8033443199; +2348067394544
}

\begin{abstract}
Information had been seen as essential element in all aspect of human and business life, without information no meaningful development can be achieved. Despite this, little or no emphasizes had been put on this great asset. The gap in information has been identify as one of the major barriers to the development of SMEs in Nigeria. This study focus on the various sources of business information, reasons for using business information, the rate of usage among SMEs, and the extent at which business information has helped in developing SMEs entrepreneurial knowledge in Lagos Metropolis. The study focused on three main construct which are Customers' Information, Multi-media Devices and Government agencies as sources of information for SMEs in Lagos Metropolis. The study used descriptive statistics, questionnaire was used as the major research instruments to obtain data from three hundred respondents drawn from twenty local council development areas of Lagos state. Data collected were presented in frequency tables and percentages while chi-square were used for the analysis. Findings of this study revealed that most SMEs in Lagos State depend on customers' information and multi-media means as their source of business information, it was also deduced that majority of surveyed SMEs have reported positive performance by utilizing business Information at their disposal in their businesses. Based on these findings, the paper recommends among others that government should provide funds to the SMEs operators to acquire new technology to expand their business. SMEs should be adequately educated and informed about the importance of business information, the use of multi-media devices like, photographs, pictures, craft displays, audio-visual materials, film shows and media houses using local languages should be encouraged at public meetings and empowerment program to give business information to SMEs operators and increases their operational efficiency.
\end{abstract}

Keywords: Information, Utilization, Entrepreneurial Knowledge, SMEs, LCDA.

Proceedings Reference Format

Adesanya, A.S. \& Adewumi, D.O. (2021): Business Information Utilization for Sustainable Entrepreneurial Knowledge among SMEs in Lagos Metropolis. Proceedings of the 27th iSTEAMS Multidisciplinary Innovations \& Technology Transfer (MINTT) Conference. Academic City University College, Accra, Ghana. June, 2021. Pp 77-94 www.isteams.net/ghana2021. DOI - https://doi.org/ 10.22624/AIMS/iSTEAMS2021/N27P9 


\section{INTRODUCTION}

Business Information today had been seen as crucial and essential element in all aspect of human life, without information no meaningful development can be achieved. Business owners now sees Information as one of the important assets that facilitate business growth. Despite the importance of information, little or no emphasizes had been put on this great asset. The gap in Information had been identify as one of the major barriers to entrepreneurship development, especially among SMEs in Nigeria. Entrepreneurship plays an important role in the economic growth and development of any nation. The purpose of the activities include: initiation, promotion and distribution of wealth and service. An entrepreneur is a critical factor in economic development and an integral part of the socio-economic transformation. It is a risk taking activity and challenging tasks which needs utmost devotion, total commitment and greater sincerity with fullest involvement for his personal growth and personality

Entrepreneurship is more than simply starting a business, it is a process through which individuals identify opportunities, allocate resources, and create value which is done through the identification of unmet needs or make opportunities for change. It is the act of being an entrepreneur which is seen as "one who undertakes innovations with finance and business acumen in an effort to transform innovations into economic goods hence Entrepreneurs see "problems" as "opportunities," and then take action to identify the solutions to those problems and the customers who will pay to have those problems solved. Entrepreneurial success is simply a function of the ability of an entrepreneur to see opportunities in the marketplace, initiate change or take advantage of changes and creates value through solutions.

The ultimate goal of every entrepreneur in small, medium or large is profit maximization. Therefore, providing prompt and relevant business information to business owners in any given environment open opportunities to gain entrepreneurial, business management and information technology skills that will enable them to start, own and operate a profitable business successfully. In today's hyper competitive business environment, entrepreneurs and business owners are increasingly under pressure to get more productive, create more value in less time, not only for themselves but also for their businesses. Entrepreneurs need to be very careful and know a lot about business information, this helps entrepreneurs to know about his or her personality, and the business as a whole.

Business information empowers every person to understand business potentiality and resource. If the person can understand or identify business traits, then it helps him choose the right path for which he should look into. For an entrepreneur it is of great importance to know about business information. According to Ononaeke (2010), business information drove the business entrepreneurial development worldwide today. In addition to the financial markets, the primary business information sources can be categories into the following: Basic reference sources such as guides, bibliographies, dictionaries, manuals, encyclopedias, handbooks, yearbooks and internet resources, Directories, Periodicals and newspapers, Loose-leaf services, Government information and services, Statistics, Electronics, business information etc. Entrepreneur, whether he is building new business or expanding the existing ones, requires the application of business information to capture new ideas and services locally to reap the economic benefits of innovation. 


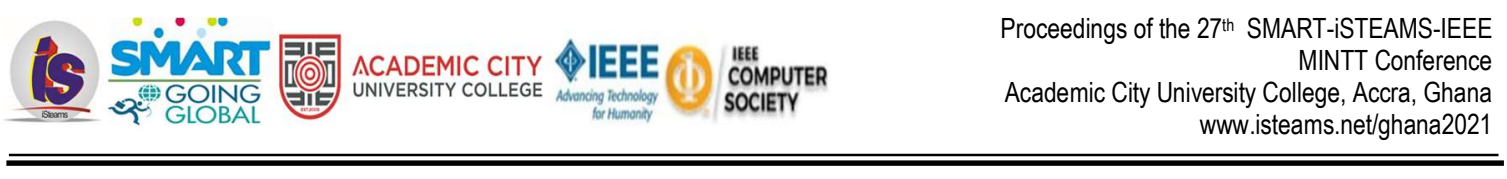

The other hand, entrepreneurship is even more relevant when supply of jobs in the labour market shrinks. Knowledge about entrepreneurship will be very useful when fresh graduates are unable to find their ideal jobs or retrenched when the economy slows down, some fresh graduates turn to entrepreneurship. In the entrepreneurship literature, this is termed necessity entrepreneurship this study was conducted to find out the utilization of business information among SMEs in Lagos Metropolis of Nigeria.

\subsection{Statement of the Problems}

Business Information is relatively a new concepts in research, Researchers are still in doubt on relevance of Business Information on Entrepreneurship, focusing on SMEs knowledge base. In many developing nations, Business information effects have yet to materialize. Many scholars, Akande, (2014); Akande \&Yinus, (2013); Oladejo and Yinus (2014) have focused on other information base research like, Information Technology adoption and business performance in developing country such as Nigeria, information accessibility etc. some questions remain unanswered regarding the Utilization of Business Information gathered over time in building the knowledge base of SMEs Entrepreneurs. When there is a lack of vital business information available, the business stands to suffer poor growth and may even crumble. It is a strategic factor that creates the right business environment for business to flourish in any competitive environment.

\subsection{Research Questions}

As a result of the gap in the utilization of business information, specifically, this study will answer the following research questions:

1. What are various sources of business information adopted by SMEs Entrepreneur in Lagos Metropolis?

2. Does Business Information adoption Influence Entrepreneurial knowledge base in Lagos Metropolis?

\subsection{Hypothesis}

Null- There is a relationship between the utilization of Business Information and SMEs operation

Alternate - There is no relationship between the utilization of Business Information and SMEs operation

The significance of this study is that it will be useful to entrepreneurs and scholars as well on the need for and utilization of business information in the development of small-medium enterprises in Nigeria. Nigeria population is estimated to be 200 million, however Lagos is the commercial capital of Nigeria and it has the largest number of small businesses. Thus the scope of this study shall be Lagos metropolis and only SMEs shall be the used as study case.

\section{LITERATURE REVIEW}

\subsection{Information}

According to Mohammed (2011), Information is any kind of event that affects the state of a dynamic system. He discussed further to describe information as anything that add value to the existing knowledge, ideas, skills and experiences positively or negatively. The concept enables individual to take decisions or react to situations immediately or later at an appropriate time. Information can be recorded as signs, or transmitted as signals. Information according to Rouse (2010) "is data that has been verified to be accurate, timely, and specific and organized for a purpose." 


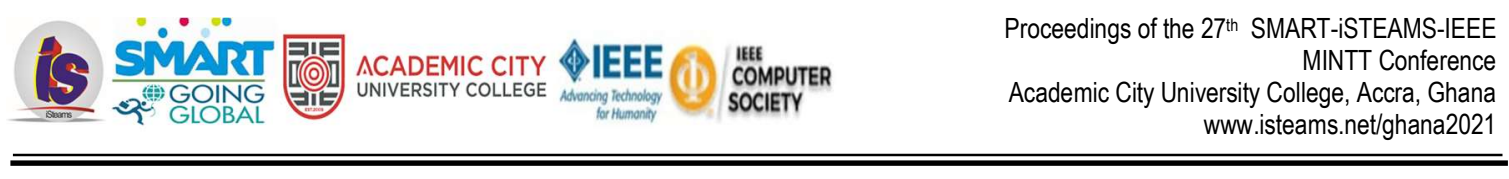

He further stated that information when presented within a context that gives it meaning and relevance, can lead to an increase in understanding and decrease in uncertainty. The value of information lies solely in its ability to affect a behavior, decision, or outcome. A piece of information is considered valueless if, after receiving it, things remain unchanged. After processing (such as formatting and printing), output data can again be perceived as information. When information is packaged or utilized for understanding or adding values, then it is known as knowledge.

Conceptually, information is the message (utterance or expression) being conveyed. This concept has numerous other meanings in different contexts. Moreover, the concept of information is closely related to notions of constraint, communication, control, data, form, instruction, knowledge, meaning, mental stimulus, pattern, perception, and representation,

\subsection{Business Information}

Churchill (2012) remarked that in planning business, one must start with a great idea. Business information exposes untapped market and good products which are indeed essential ingredients in any recipe for success. Developing a business idea through viable business information is a matter of creating a vision, leveraging your strengths and determining what the market needs. Churchill (2012) enumerates some ways entrepreneurs use business information to achieve business objectives as follows:

I. To achieve operational excellence

ii. To obtain new products, services and business models

iii. Acquire customer/supplier intimacy

iv. Improve decision making

v. Learn competitive advantage

Vi. For day to day survival of the business

Appropriate use of business information is responsible for the proper and efficient management of business enterprise. SMEs find it difficult to make decisions with little or no information as invoices, purchase orders and other documents. These are other sources of business information that are needed to be organized and controlled but are really difficult to maintain because of the level of education of entrepreneurs in some SMEs, nature of the customers and business environment. In the case of their counterparts in the urban areas, such records are adequately organized and controlled in order to prevent theft, loss of information at the point of sales and within business premises. Generating business ideas begins with the creative process of creating plan from information gathered to set goals and visualizes how to achieve them. These are the foundation for successful entrepreneurship development.

\subsection{Sources of Business Information}

According to Ononaeke (2010) business information traditionally aid the business entrepreneurial development globally in recent times. In addition to the financial markets, the primary business information sources can be divided into the following categories: Basic reference sources such as guides, bibliographies, dictionaries, almanacs, encyclopedias, handbooks, yearbooks and internet resources, Directories, Periodicals and newspapers, Loose-leaf services, Government information and services, Statistics, Electronics, business information etc. Entrepreneur, whether he is building new business or reinventing the existing ones, requires the application of business information to capture new ideas and services locally to reap the economic benefits of innovation. 


\subsection{Small-Medium Enterprises}

Small and medium Business has been recognized as an instrument of economic growth and sustainable development. This growing recognition has led to the commitment of World Bank group on SMEs sector as core element in its strategy to foster economic growth, employment and poverty alleviation. The importance of small and medium scale enterprises has not been in doubt; unfortunately classifying businesses into large and medium scale is subjective and premised on different value judgment. Such classification has followed different criteria such as employment, sales or investment for defining small and medium scale enterprises. There is no universally acceptable definition of small and medium enterprises, even in a given country, different institution, may adopt different definition depending on their focus and objectives. According to Ayyagari, Beck, and Demirguc-kunt (2003) that in the existing literature the definition vary in different economies but the underlying concept is the same. The definition of SME depends on factors like level of the economy (boom or recessed), government policy through annual monetary policy and guidelines, number of employees, the capital amount, market, revenue and profit size.(Adesanya, 2019)

Across the globe SME is defined differently by various countries. In Britain, the standard definition of small business is a business with an annual turnover less than two million pound starting or less with a less than two hundred (200) paid employees. In Japan it is conceptualized as type of industry, paid up capital and number of employee. Consequently small and medium scale enterprises are defined as those manufacturing with 100 million yen paid up capital and 300 employees. Those in wholesale trade with 300 million paid up capital with 100 employees while those in retail trade with 100million paid up capital with 50 employees. .(Lawal, Kio,Sulaimon \& Adebayo,2006). The European Union (EU, 2005) as cited by Eniola (2014) defined micro, small and medium enterprise (MSME) as micro enterprise with number of employees below 10 and turnover and balance sheet is not more than two (2) million euro, small enterprises is an enterprise with number of employees not more than 50 and turnover and balance sheet is not more than 10 million Euros while medium scale business is an enterprise with number of employees not more than 250 and turnover/ balance not more than 50 million Euros. In the United State of America, Small Business Administration (SBA) defined this sector as one that is independently owned and operated, is not dominant in its field and meet up employment or sales standard developed by the agency.

As contained in its Industrial Statistics, The Ghana Statistical Service (GSS) (n.d.) considers firms with less than 10 employees as Small Scale Enterprises and their counterparts with more than 10 employees as Medium and Large-Sized Enterprises. In Nigeria, the multiplicity of the definition is quite apparent, the definition and classification of SMEs in Nigeria is in terms of capital employed, turnover and number of employees. SMEDAN (2005) defines SMEs based on the following criteria: small scale enterprises are businesses with ten to fortynine people (10-49) with an annual turnover of five to forty-nine million Naira (\#5-49million) while a medium scale enterprises that have fifty to one hundred and ninety-nine employees (50-199) with a year turnover of fifty to four hundred and ninety-nine million Naira, (\#50-499million) (Muhammed, et al 2015) Hamitle, (2011) as cited in (Adesanya, 2014) Micro-cottage industries is defined as those whose total investment cost does not exceed \#1.5million including working capital but excluding cost of land and the workforce is not more than 10. Small scale industries is defined as those whose total investment cost is between \#1.5million to \#50million including working capital but excluding cost of land and the workforce is between 11 and 100 workers. Mediumscale industries is defined as those whose total investment cost is between \#50million to \#200 million including working capital but excluding cost of land and the workforce is between 101 and 300 workers. Large- scale industries is defined as those whose total investment cost is over \#300 million including working capital but excluding cost of land and the workforce is over 300 workers. 


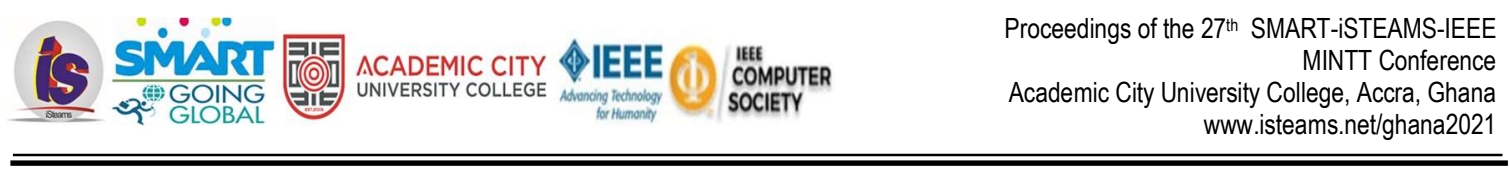

Therefore, SME is any business enterprise that is highly personalised, situated within a local area of operation, which is relatively small in term of size, employment, turnover and capital and is actively managed by one or few persons for the purpose of making profit (Adesanya, 2014). In Nigeria, SMEs cover economic activities within all sectors. It is clear from the various definitions, showing that there is no single concept that constitutes SMEs; the definitions vary across industries and the globe. SMEs are heterogeneous group, and SMEs owners may or may not be poor. Some are dynamic, growth-oriented, and innovative while others are not; they preferred to remain small and also to continue as usual these are Fabian entrepreneurs Sokan (1996) retorted that the essential features of SME are that managers are the owners and owners. The owners of the business actively participate in all aspects of the management and highly personalized. The capital is supplied by an individual or small group of persons and finally their area of operation if localized. Lawal. Kio,Sulaimon and Adebayo (2006) states that the characteristics of SME is that the business is independently owned, independently managed, highly personalized, financed mainly from internal sources, largely local in its operation and small in terms of sales turnover, number of employees, asset value, profits within the industry.

Gbandi and Amissah (2014) there is no reliable database on SMEs in Nigeria and so it is difficult to accurately determine the number of SMEs in Nigeria. However, the Small and Medium Enterprises Development Agency of Nigeria (SMEDAN) using data collected from the National Bureau of Statistics (NBS) is working on the publication of its first comprehensive database of small businesses in Nigeria (leadership newspaper 05/03/2012). A recent survey conducted by the national bureau of statistics indicate that Anambra state has the highest number of SMEs in Nigeria (vanguard Newspaper, 2012) and they also led in four industrial sectors including automobile industry. However this is subjective as it is observe that there are more Nano-cottage and micro-cottage enterprises in Lagos state than any other state in Nigeria, reason being the mega city and commercial centre of the country.

The importance of Micro, Small and Medium Enterprises (MSME) in the development and growth on any nation cannot be underestimated as they perform distinctive and important functions and serve as the backbone of the economy. In Nigeria, the Small and Medium Scale Enterprises (SMEs) is the driving force and establish an important mainstay of the Nigerian economy. This sector economically, holds the key to sustainable development of the country and its importance can be put in proper aspect in relation to the structure of the Nigerian economy with many performance contributions as the source of technology innovation and new products (Jocumsen 2004: The federal office of statistics (2012)

Report affirmed the importance of SMEs, when it revealed that about 86 percent of the entire enterprises in the country are SMEs and they employed an average of 50 percent of the working population, as well as contributing to 54 percent of the country industrial output. The performance and role of NSMEs going forward are bound to be even greater and more pervasive with a demonstrable impact on the emerging economy. NSME is the driving force and establish an important mainstay of the nation's economic system. The evolution of this sector leads to poverty relief, employment creation and multiplication of potential entrepreneurs. It offers linkage development of large industries. Lawal. Kio, Sulaimon and Adebayo (2006) opined that SMEs promote indigenous technology, moderation of rural urban migration, higher value added to domestic economics, promotion of effective domestic production, prevention of monopoly regional economic imbalance among others. Udechukwu (2003) opined that SMEs indeed possess enormous capability to grow an indigenous enterprise culture more than any other strategy. 


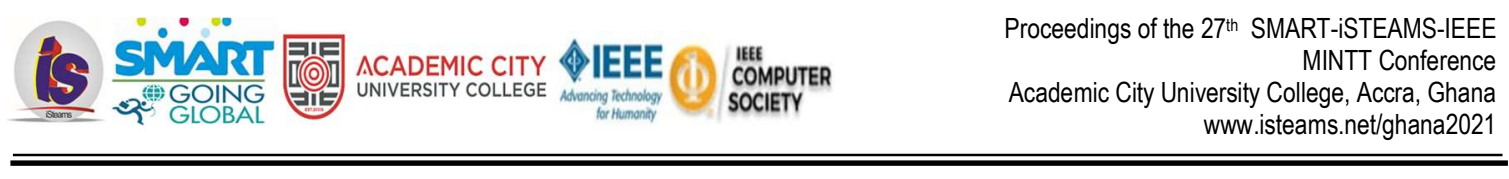

Thus, from the planning point of view, SMEs are increasingly recognised as the principal means for achieving equitable and sustainable industrial diversification and dispersal, and in most countries SMEs account for well over half of the total share of employment, sales and value added, most especially in Nigeria.

Oluba (2009) as cited in Eniola, (2014) observed that the importance of SMEs varies with sectors and with the developmental stage of a country. He opined that developing characteristics such as the degree of capital allocation and requirements, management size and arrangement as well as limited market access which makes SMEs less amenable to the unsatisfying effects of growth schemes that concentrate on large, capital intensive and high import dependent industrial plants as well as failed public enterprises.

\subsection{Business Information and SMES}

\subsubsection{Impact of Business Information on Small Medium Enterprise (SMEs)}

Banabakova and Panev (2009) sees business information as a logistical service employed by an entrepreneur to create customer relationship management. It is designed to improve the marketing services and logistical campaigns for better services, customer loyalty and to generate a greater income. Business information stimulates the effective relationship with customers, which influences the strategy and culture of the enterprise. This means that the management of the main business processes like the advertisement, business publicity, production and supply information, distribution etc depends on the accurate and appropriate business information. The effective management of an enterprise and the increase in productivity as well as business promotion are all aspects of business information.

From time immemorial, society have brought men to live and work together to achieve common goals. This is done through communicating information from one person to another. Vaughan (2006) stated that "business information is a kind of information that has been provided to the business community." Various kinds of business information services is apparent to business operations including publicly funded ones such as the public library business information services. To serve the business community well, information professionals need to know the sources and approaches used by the business community to gather information.

For business to succeed there is need for adequate and appropriate communication and utilization of business information to the business community. Until today business information has been the most effective resource to modern business. Brenda, Bennett and Shipsey (2002) assert that "business information is primarily responsible for the proper and efficient management of business enterprise." Business information is rather important in any entrepreneurship development hence it is focused on different areas of the enterprise. Some examples include: managing the relationship with customers, management supply chain, production resource management and business intelligence.

The role of business information is very important for the survival of business but also for the day to day business transaction. This indicates that when there is a lack of vital business information available, the business stands to suffer poor growth and may eventually crumble. It is a strategic factor that creates the right business environment for business to flourish in any competitive environment. It focuses on development of public business especially as it relates to promoting the best entrepreneurial environment to start and expand the business. 


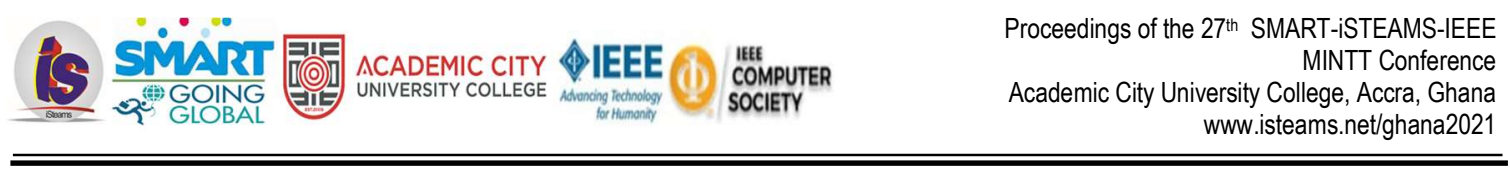

American Labour Force (2012) typifies that business information is a major and vital key in the success of any enterprise. For instance, what do you think will happen if there is no way this information is passed on to the relevant customers? The application of business information in business entrepreneur is to improve sales and services, increase customer awareness and promote the entrepreneurship development. Thus, lack of business information can leads to inadequate publicity which can affects customer patronage. When there is no adequate information on business enterprise there will be low patronage, low sales and low profits. Another effect is that it brings about confusion in the business. It can also impede business progress, destroys customer and client relationship and increases financial crises.

\subsubsection{Business Information and Entrepreneurial Knowledge}

Meyer (2005) viewed business information as a resource which like other resources should be managed to give a competitive edge. This implies that business information as a resource should be managed in such a way to produce further benefits that will enhance business prosperity and knowledge. It is in line with this that Aruwa (2005) sees business information as one of the important resources needed by SMEs development. A business entrepreneur goes through stages of development, knowledge acquires today will change and require different approaches to be successful. Aruwa (2005) identified attributes of business information as operational excellence, new products, services and models, customer and supplier intimacy, improved decision making, competitive advantage, business survival, and knowledge base development.

The Great Soviet Encyclopedia (2010) defined business information as a message transmitted from certain persons to other persons by verbal, written or any other means. This entails the use of any form of medium through which information can be conveyed to the business owners as well as the potential customers. Business information is viewed as the most important singular variable, which differentiates and determine whether the enterprise is developing or not. This means that business information is a yardstick for rating the business organizations in terms of development. It can liberate an entrepreneur from the shackles of economic darkness; access to it is a fundamental right as such rural entrepreneur needs it just like the urban entrepreneurs.

From the above, one can summarize that business information is facts and opinion provided and received during the course of daily business transaction. Business information can be obtained directly from people, mass media, and library and even within the society through observation. The analysis has revealed that business information is different from most other information. The very fact that business information is characterized as a dynamic force constantly changing and extending knowledge that corresponds with situations in business development in which outside information is offered to target groups to influence their understanding of certain business potentialities, which in turn can help solve problems such as improving standard of living.

\section{METHODOLOGY}

As at the period of this research 4,535 registered SMEs in Lagos constitute the study population of the research. For purpose of this study the population was drawn from the list of registered member of national association of small scale industrialist (NASSI) Lagos State Chapter. The research use Lagos State as a study for this research due to the fact that Lagos has high degree of socio-economic activities and serve as a settlement state that accommodate diverse ethnics and business enterprise from other part of country which consequently lead to its rapid market expansion. 
Lagos State was stratified into Twenty (20) Local Council Development Area (LCDA) from which the sample of various Associations of small medium scale business was drawn through the simple random sampling procedure. Three hundred (300) Questionnaires were purposively administered and distributed to the members of association of small scale enterprises (NASSI) across all the (20) LCDA in Lagos State, consisting of manufacturing, services businesses, printing businesses, food vendors and restaurants, business centers, and Artisan with employment capacity ranging from 2-30 employee. The data collected were analyzed using descriptive and inferential statistical tools. The descriptive statistics used included percentages and tables while Chi-Square was used to analyses the study hypothesis. Fifteen (15) NASMEs each was picked from the twenty (20) LCDA due to their approved and recognition by the Federal Government. The questionnaire consists of questions that are related to business Information, the Utilization of Business Information, Sources of Business Information as identified in the literature. Data collected coded and analyzed using frequency table, percentage and mean score while non-parametric statistical test (Chi-Square) was used to test the formulated hypothesis using STATA Data Analysis Package/Software.

\section{RESULTS AND DISCUSSIONS}

In this section we present the results of our data analysis as well as discussions

Table 1: Demographic Representation

\begin{tabular}{|l|l|c|}
\hline Sex & Option & Percentage\% \\
\hline Male & 180 & 60 \\
\hline Female & 120 & 40 \\
\hline
\end{tabular}

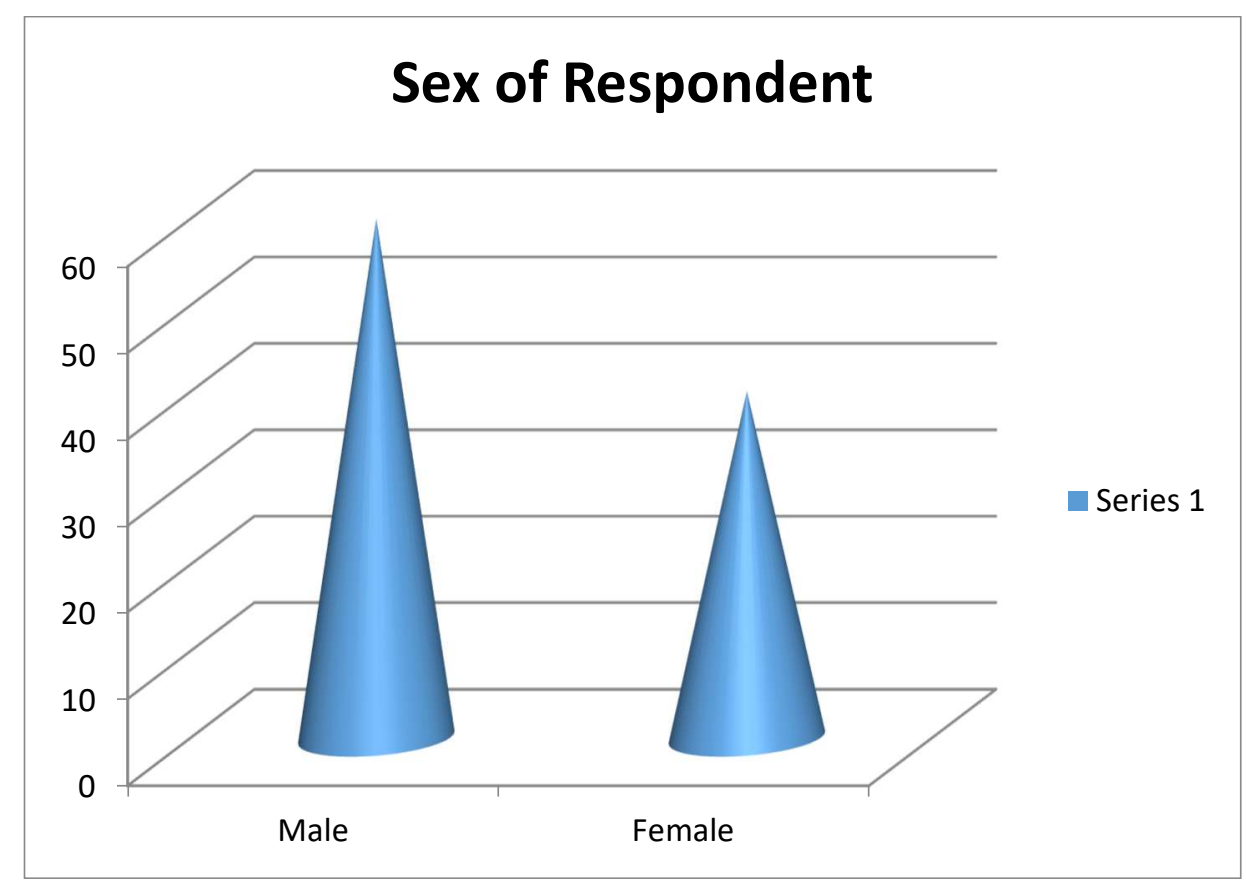

Figure 1: Sex of Respondents 
From Table $1,60 \%$ of the respondents are male while $40 \%$ of the respondents are female. This implies that the Male respondents in this research engage more in SMEs in Lagos Metropolis and their views will be considered as an important tool for this research.

Table 2: Level of Education

\begin{tabular}{|l|l|l|}
\hline Level of Education & Option & $\%$ \\
\hline PhD & Nil & Nil \\
\hline MSc. & 10 & 3 \\
\hline BSc & 10 & 3 \\
\hline HND & 180 & 60 \\
\hline ND & 100 & 33 \\
\hline SSCE & Nil & Nil \\
\hline
\end{tabular}

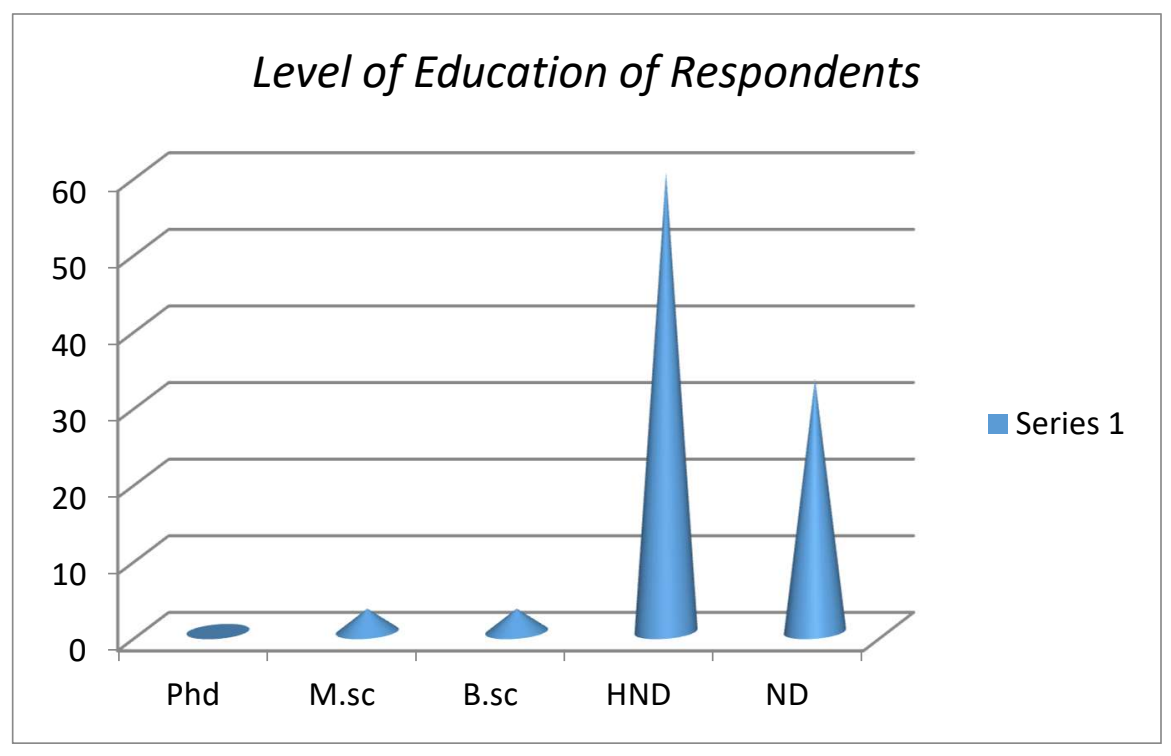

Figure 2: Graphical representation of Respondents level of education

From the above table 2, HND has the highest value of $60 \%$ showing that most SMES operators in Lagos Metropolis are HND holder that needs more information about their business operations.

Table 2: Marital Status of Respondent

\begin{tabular}{|l|l|l|}
\hline Marital Status & Option & $\%$ \\
\hline Married & 170 & 57 \\
\hline Single & 130 & 43 \\
\hline
\end{tabular}




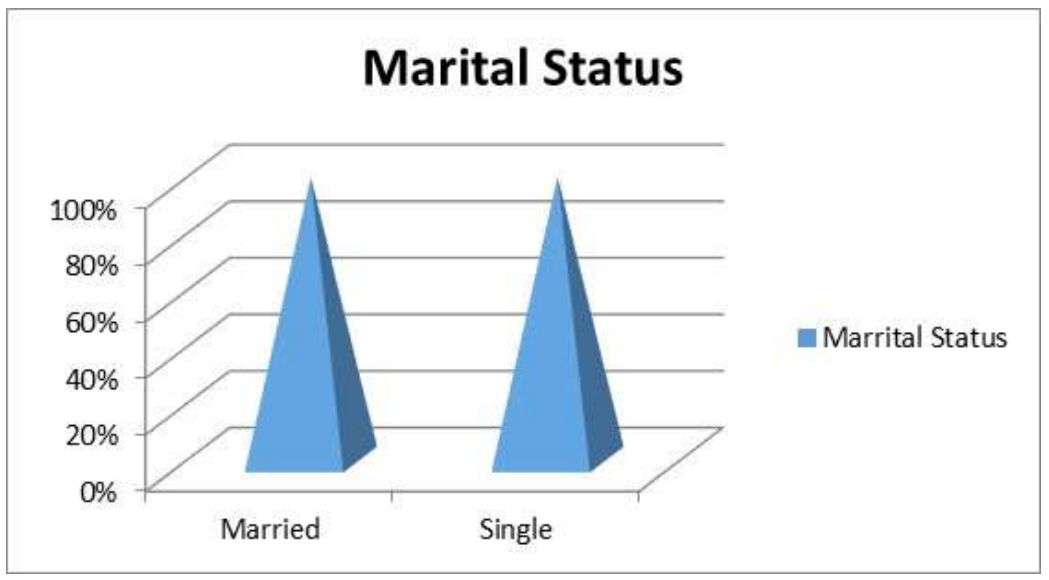

Figure 3: Graphical representation of respondents marital Status

From the above table 3 above, $57 \%$ of respondent are married, $43 \%$ are single this shows that most of the SMEs operator in Lagos Petropolis are married which make them mature for this study.

Table 4: Age group of the respondents

\begin{tabular}{|l|l|l|}
\hline Age Group & Option & $\%$ \\
\hline $25-35$ & 50 & 17 \\
\hline $35-45$ & 120 & 40 \\
\hline $45-55$ & 100 & 33 \\
\hline $55-60$ & 30 & 10 \\
\hline
\end{tabular}

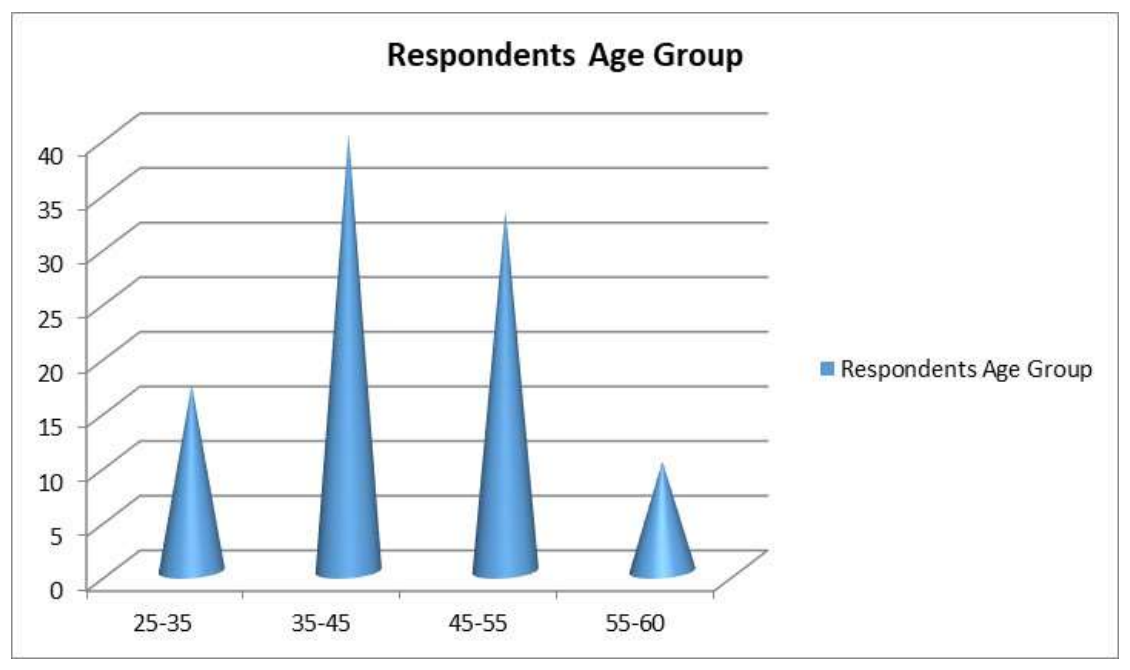

Figure 4: Graphical representation of respondent age group 
From the Figure 4 above, it shows ages 25 to 35 respondents to be $17 \%, 35-45$ shows to be $40 \%, 45-55$ shows to be $33 \%$ and ages $55-60$ representing $10 \%$. From the above, it is clearly seen that the age group $35-45$ which represent $40 \%$ has the highest value and this can be said that active youth engage in SMEs operation in Lagos Metropolis.

\subsection{Section B: Answering Research Questions}

Table 5: What are various sources of business information adopted by SMEs Entrepreneur in Lagos Metropolis?

\begin{tabular}{|l|l|l|l|l|l|l|l|l|}
\hline $\begin{array}{l}\text { Tools adopted by SMEs Entrepreneur } \\
\text { in Lagos Metropolis }\end{array}$ & \multicolumn{10}{|c|}{ Sources Response Rate } \\
\hline Options & Yes & $\%$ & No & $\%$ & Undecided & $\%$ & Total & $\%$ \\
\hline Customer Information & 250 & 83 & 45 & 15 & 5 & 2 & 300 & 100 \\
\hline Multi Media Devices & 200 & 67 & 70 & 23 & 30 & 10 & 300 & 100 \\
\hline Government Information & 100 & 33 & 160 & 67 & 40 & 5 & 300 & 100 \\
\hline
\end{tabular}

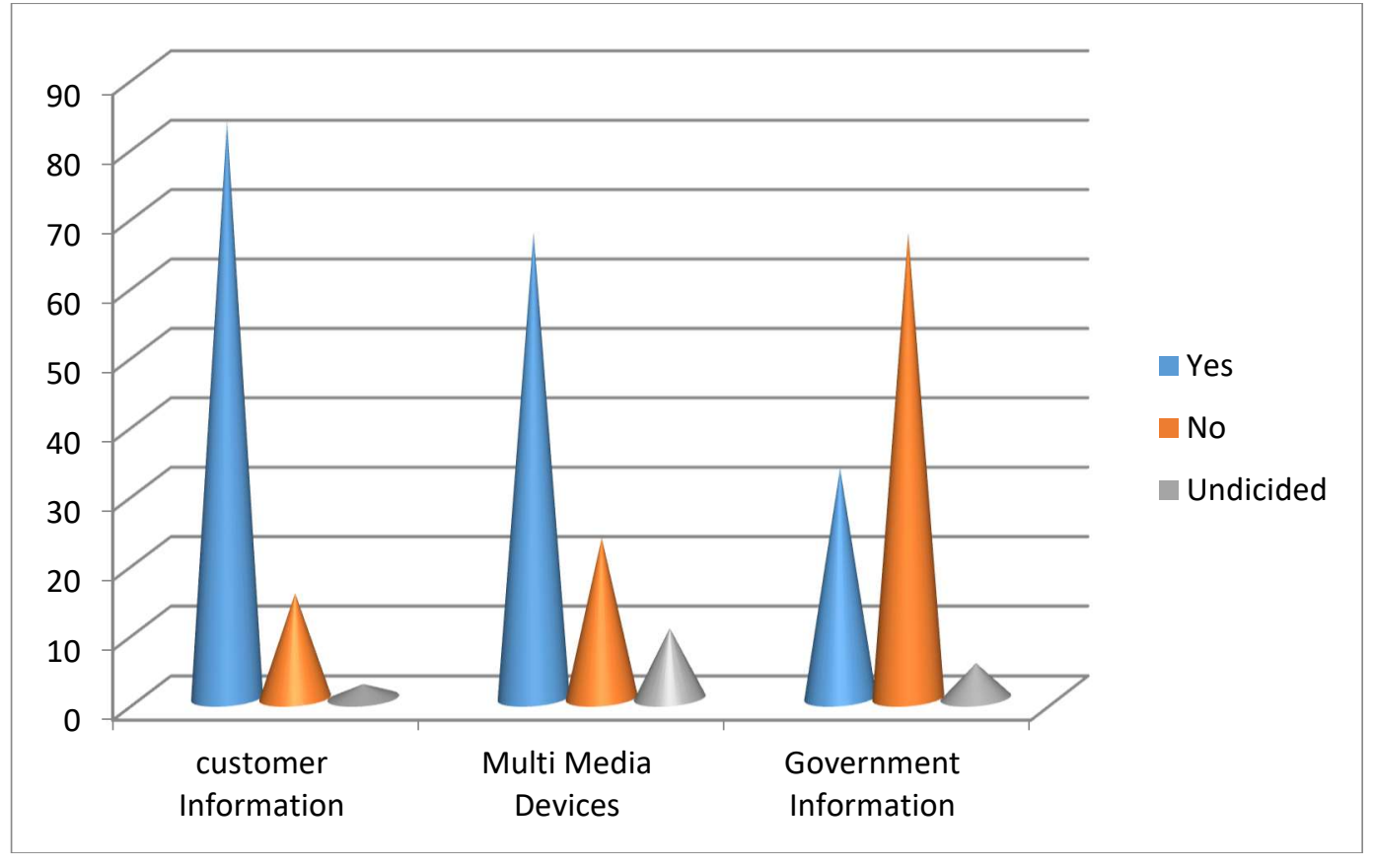

Figure 5: Graphical representation of sources of business information adopted by SMEs Entrepreneur in Lagos Metropolis? 
Table 6: Does Business Information adoption Influence Entrepreneurial knowledge base of SMES in Lagos Metropolis?

\begin{tabular}{|l|l|l|l|l|l|l|l|l|l|l|l|}
\hline & \multicolumn{9}{|c|}{ Response Rate } \\
\hline & $\begin{array}{c}\text { Strongly } \\
\text { Agree }\end{array}$ & \multicolumn{2}{|c|}{ Agree } & \multicolumn{2}{|c|}{ Uncertain } & \multicolumn{2}{c|}{$\begin{array}{c}\text { Disagree } \\
\%\end{array}$} & $\begin{array}{l}\text { Strongly } \\
\text { Disagree }\end{array}$ \\
\hline & Freq & $\%$ & Freq & $\%$ & Freq & $\%$ & Freq & $\%$ & Freq & $\%$ \\
\hline $\begin{array}{l}\text { Options } \\
\text { Business Information Improves }\end{array}$ & 260 & 87 & 20 & 6 & 05 & 2 & 10 & 3 & 5 & 2 \\
\hline $\begin{array}{l}\text { Business Information help to } \\
\text { Generate Business Ideas }\end{array}$ & 190 & 63 & 98 & 33 & 10 & 3 & 2 & 1 & Nil & Nil \\
\hline $\begin{array}{l}\text { Business Information aid } \\
\text { learning competitive } \\
\text { advantage }\end{array}$ & 155 & 51 & 54 & 18 & 50 & 17 & 20 & 7 & 21 & 7 \\
\hline $\begin{array}{l}\text { Business Information bring } \\
\text { about positive performance in } \\
\text { business }\end{array}$ & 250 & 83 & 20 & 7 & 10 & 3 & 20 & 7 & Nil & Nil \\
\hline $\begin{array}{l}\text { Business Information has } \\
\text { positive Influence on SMEs } \\
\text { operations }\end{array}$ & 220 & 73 & 20 & 7 & 30 & 10 & 25 & 8 & 5 & 2 \\
\hline
\end{tabular}

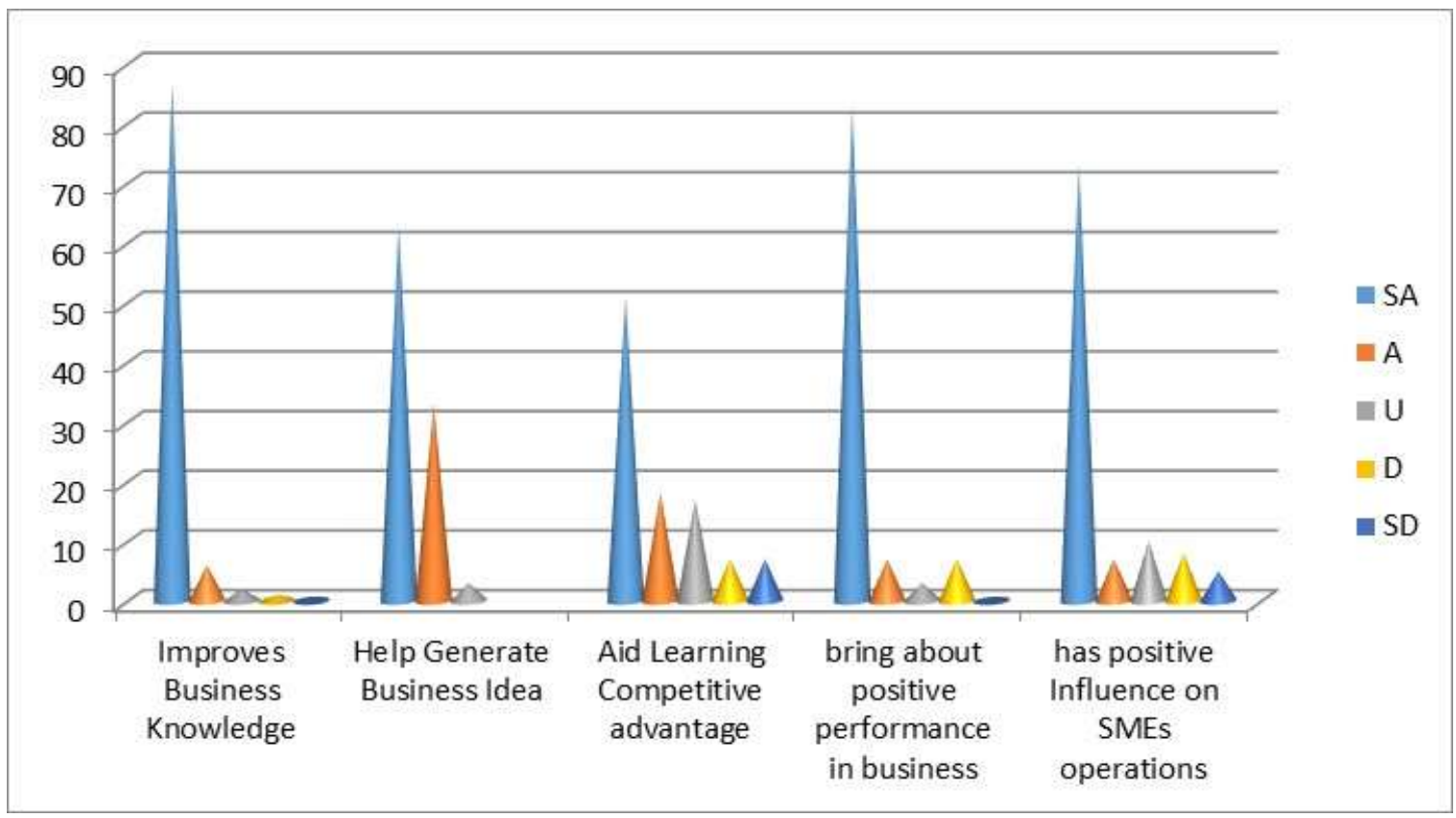

Figure6 Graphical representation of Distributions of Respondents on the Extent of Use of Business information 


\subsection{Test of Hypothesis:}

There is no relationship between the Utilization of Business Information and Entrepreneurial Knowledge in SMEs operation in Lagos Metropolis

Table7: Relationship between Utilization of Business Information and Entrepreneurial knowledge as in SME using Chi-Square Analysis.

\begin{tabular}{|l|l|l|l|}
\hline $\mathrm{N}$ & Pearson Chi-Square (Value & $\operatorname{Pr}($ Value) & Remark \\
\hline 1 & 120.3027 & 0.000 & Significant \\
\hline 2 & 166.4675 & 0.000 & Significant \\
\hline 3 & 100.5552 & 0.000 & Significant \\
\hline 4 & 168.1618 & 0.000 & Significant \\
\hline 5 & 161.0158 & 0.000 & Significant \\
\hline 6 & 116.0760 & 0.000 & Significant \\
\hline 7 & 180.6207 & 0.000 & Significant \\
\hline 8 & 107.3895 & 0.000 & Significant \\
\hline 9 & 158.6806 & 0.000 & Significant \\
\hline 10 & 174.9242 & 0.000 & Significant \\
\hline 11 & 146.4915 & 0.000 & Significant \\
\hline 12 & 117.5979 & 0.000 & Significant \\
\hline 13 & 93.4343 & 0.000 & Significant \\
\hline 14 & 232.3232 & 0.000 & Significant \\
\hline 15 & 156.9562 & 0.000 & Significant \\
\hline
\end{tabular}

Source: Computations and Out-Put from STATA 10 based on Field Survey.

\section{DISCUSSION}

From the Tables above it can be deduced that the customer information with the highest percentage of $83 \%$ is the main source of Information for SMEs operators in Lagos Metropolis, the SMEs relay on information from customers to improve on their business. Multimedia devices with $67 \%$ is the next most use options by the SMEs in Lagos Metropolis, this implies that gadget list Mobile phones, internet, radio, television etc are being used for business information purposes. Government information is the least used option by the SMEs in Lagos Metropolis, with $33 \%$ response rate.

It can be deduced that out of the three option focus on in this research, the Customer Information has the highest percentage of respondent that use it for their Business growth. The next research question which is "Does Business Information adoption Influence Entrepreneurial knowledge base of SMEs in Lagos Metropolis was measured in table 2 and graphically represented in figure 2 the research want to know if the adopted option which is customer information has an influence on the knowledge base of SMEs in Lagos Metropolis from the analysis above, it can be deduced that 250 respondent agreed that Business Information adopted Improves their Business Knowledge. Which means that the customer information option adopted actually have impact on the entrepreneurial knowledge of the SMEs in Lagos Metropolis. Finally, To know If there is any relationship between the Utilization of Business Information adopted by SMEs in Lagos Metropolis and Entrepreneurial Knowledge Base in SMEs. 


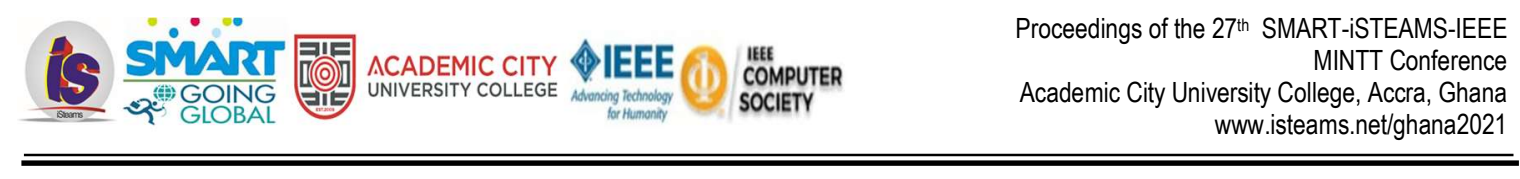

The Prime Value (pr) of 0.000 significance which means that Customer Information has a significant impact on the Entrepreneurial knowledge base and operations of SMEs in Lagos Metropolis which lend credence to the fact that There is a relationship between the utilization of Business Information and SMEs operation.

\section{CONCLUSION}

Based on the findings of this study, it is concluded that SMEs in Lagos Metropolis depend on Customer information and multimedia devices for their business information and this has a positive influence on their businesses and operations. The information gotten from customers are used to improve their knowledge.

\section{RECOMMENDATION}

In view of the findings from the research work, the following recommendations were made as follows:

$>$ SMEs should be adequately educated and informed about the importance of Business Information and how it could be utilized to increase operational efficiency.

$>$ Information disseminators should communicate in a precise and clear terms, Utilization of indigenous languages by information disseminators like the media houses to convey information regarding business should be encourage.

$>$ The use of multi-media devices like, photographs, pictures, craft displays, audio-visual materials, film shows should also be used to give business information to SMEs

$>$ Government should be more proactive to their responsibility in regarding information dissemination, it was deduced from the findings that SMEs has lost confidence in Government in regarding their Business Information, hence, they focus on other sources of information.

$>$ Other sources of Information should also be used by the SMEs to broaden their horizon in Business Information and the uses

\section{REFERENCES}

1. Achintya, S. K. and Com, B. M. (2006). Entrepreneurship: Concepts and Definition. Indian Institute of Entrepreneurship: Ministry of Industry.

2. Adesanya A,.S. (2014) Small and medium enterprises (SMEs) development in Nigeria: Nature, challenges and prospects; International Journal of Management Sciences and Humanities Volume 2 (2)

3. Adesanya, A,.S. (2019) Small and Medium Enterprises as a Tool for Sustainable Development in Nigeria - So far. Being a Paper Presented and Delivered at International Conference on Entrepreneurship at Mountain Top University Prayer-City, Magboro Ogun-state, Nigeria

4. Agboola, A.A. (2001) Impact of Electronic Banking on Customer services in Lagos, Nigeria, Ife Journal of Economics and Finance, vol 5, Nos. 1 and 2.

5. Akande 0.0 (2015) Journal of Business and Management (IOSR-JBM) e-ISSN: 2278-487X, p-ISSN: 2319- 7668. Volume 17, Issue 4.Ver. V (Apr. 2015), PP 19-24 www.iosrjournals.org

6. Akande and Yinus (2013): An Appraisal of the Impact of Information Technology (IT) on Nigeria Small and Medium Enterprises (SMEs) Performance. International Journal of Academic Research in Management (IJARM) Vol. x, No. x, Month Year, Page: x-y, ISSN: 2296-1747

7. Aruwa, S. A. S. (2005). The Business Entrepreneur: Entrepreneurial Development, Small and Medium Enterprises. Kaduna: Entrepreneurship Academy Publishing. Pp. 4-11 
8. American Labour Force (2012). Effects of Lack of Communication in Business Information: Micro Entrepreneurship Development for Women and Youth. Retrieved on 20/04/2012 from http://www.mysticmadness.com/effects-of-communication-in-business.html.

9. Aruwa, S. A. S. (2005). The Business Entrepreneur: Entrepreneurial Development, Small and Medium Enterprises. Kaduna: Entrepreneurship Academy Publishing.

10. Ashley, C. and Maxwell, S. (2001). Rethinking Rural Development: Development Policy Review, 2001, $19(4)$..

11. Australia Government Department of Education, S. a. (2000). Retrieved August Wednesday, 2009, from www.dest.gov.au

12. Ayyagari, M., T., Beck \&,Demirguc-Kunt A, (2013).Small and Medium Enterprises across the Globe. Small Business Economics, 29: 415-434

13. Banabakova, V. and Panev, A. (2009). Characteristics of Business Information Systems and their Importance for the Improvement of Logistical Service. Bulgaria: National Military University.

14. Binks and Vale (2016). Phenomenology and education research. A paper presented at AARE Conference, Fremantle, and December.

15. Brenda, W., Bannette, R. and Shipsey, R. (2002). Information and the Small Manufacturing Firm. British Library Research and Development Department. BLRD Edinburg: Capital Planning Information Ltd.

16. Chigunta, F.; Schnurr, J.; James-Wilson, D.; Torres, V. (2005): Being "Real" about Youth Entrepreneurship in Eastern and Southern Africa, Implications for Adults, Institutions and Sector Structures, SEED Working Paper No. 72, ILO, Geneva.

17. Clarke, J. (2004) "Information Systems Strategy and Knowledge-based SMEs in the Australian Biotechnology Industry: Does IS need to reorient its Thinking?" 15th Australian Conference on Information Systems, Hobart, Australia, 1-3 December

18. Coate, S. and M. Ravallion. (1993). Reciprocity without Commitment: Characterization and Performance of Informal Credit Markets. Journal of Development Economics, Hunter College Department of EconomicsWorking Paper .

19. Conning, J. (2005). Monitoring by Delegates or by Peers? Joint Liability Loans Under Moral. Curtain. (2000). Towards a Youth Employment Strategy, Report to the United Nations on Youth Employmet.

20. Dutta, S., and Coury, M, E. (2003) "ICT Challenges for the Arab World", Chapter 8, in Dutta, S.,

21. Entwistle, R. (2008). Entrepreneurship and Youth. Waco, Texas.

22. Emmanuel Sife A (2008): Challenges of Managing Information and communication technologies for educational Experiences from Sokoine National Agricultural Library International Journal and education and development using ICT vol 4 No3.

23. Enikanselu, S. A. and Oyende, A. I. (2005). Introduction to Entrepreneurship. Lagos: Olas Ventures. Pp. 13-14.

24. Eniola, A., A.(2014) The Role of SME Firm Performance in Nigeria Arabian Journal of Business and Management Review (OMAN Chapter) Vol. 3, (12); July.

25. Gbandi, E. C. \& Amissah, G. (2014) Financing Options For Small and Medium Enterprises European Scientific Journal January edition vol.10, (1)

26. Gregory, S., Fernandez, W, Holtham, D, Martin, S, Vitale, M, \& Pratt, G. (2004) "Achieving Value From ICT: Key Management Strategies", Department of Communications, Information Technology and the Arts, ICT Research Study, Canberra.

27. Gulf Base (2008). "GCC Common market set to enrich ICT sector" [online] 
28. Hassan D, Y, .Maina M., G., \& Mahammad U, U. (2016) The Role of Micro Small And Medium Enterprises in the Economic Development of Nigeria

29. ILO. (2008, October). Global Employment Trends for Youth. Retrieved June 21, 2009, from http://www.ilo.org/: http://www.ilo.org/wcmsp5/groups/public/---deports/-dcomm/documents/publication/wcms_077664.pdf

30. Ishaya R. A (2015) : Utilization of Business Information for Rural Entrepreneurial Development in Kaduna State. Master Thesis on Library and Information Science Iwhiwhu, E. B. (2011): Information Repacking Library Services: A Challenges to Information Professionals in Nigeria. Library Philosophy and Practices. Retrieved on 13/06/2012 from http://www.unilib/unl.edu/lpp/iwhiwhu.html.

31. Jocumsen G. (2004). How Do Small Business Managers Make Strategic Marketing Decisions? A Model Of Process. European Journal Of Marketing, 38(5/6), 659-674.

32. Karlan, D. (2007). Social Connection and Group Banking. Economic Journal , 117, F52-84.

33. Kanothi, (2009). Impact of ICT on Corporate Performance, Productivity and Employment Dynamics", Special Report No 01/2006, European Commission Enterprise \& Industry Directorate General, Berlin. KOM 2008, Knowledge Oasis Muscat [online]

34. Kozak, T.O. (2007). "Toward a Territorial Approach to Rural Development." Electronic Journal of Agricultural and Development Economics, 38 (4).

35. Lawal, A,.A,. Kio, J,.S. .Sulaimon, A.A..\& Adebayo, I,.O. (2006) Entrepreneurship Development in Small-scale Business Lagos, Akolaz ventures

36. Liedholm C and Mead D (1987). Small Scale Industries in Developing Countries: Empirical

37. Evidence and Policy Implications', International Development Paper No.9, Dept of Agricultural Economics, Michigan State University, East Lansing, MI, USA.

38. Lange, T., Ottens, M., and Taylor, A. (2000). "SMEs and Barriers to skills development: A Scottis Perspective", Journal of European Industrial Training, Vol. 24, No. 1, pp. 5-11.

39. Lanvin, B. \& Paua, F. (ed.) "The Global Information Technology Report 2002-2003: Readiness for the Networked World", World Economic Forum/Oxford University Press, New York,

40. Making Youth Programs Work. (1999) International Youth Foundation. Retrieved from http://www.iynet.org/printWin.cfm

41. Martin Binks and Philip (2018). Vale, Entrepreneurship and Economic Change, Berkshire, England: McGraw-Hill Book Company Limited, 1990, pp. 178, £ 19.95

42. McNulty, Michael; Nagarajan, Geetha. (September 2005). Serving Youth with Microfinance: Perspectives of Microfinance Institution and Youth. Chemonics International. USAID

43. Meyer, H. W. T. (2005). The Nature of Information and Effective Use of Information in Rural Development. In Information Research. Vol. 10 (2) Paper 214. Retrieved on 17/07/2012 from http://www.informationR..net/ir/10.2paper214.html.

44. Mohammed ,S A, Aminu A, Rahama L,. A, Kamalu U, Murtala B,. U, Ibrahim T,. S, Lawan S,. A.(2015). The Nature of Small and Medium Scale Enterprises (SMEs): Government and Financial Institutions Support in Nigeria International Journal of Academic Research in Business and Social Sciences March 2015, Vol. 5, No. 3 ISSN: 2222-6990

45. Nigeria- Population Reference Bureau. (2007). Nigeria Statistics. Retrieved June 22, 2009, from Population Reference Bureau: http://www.prb.org/Countries/Nigeria.aspx 93

46. N'jie, M. A. (1991). "The Gambia Technical Training Institute," in Entrepreneurial Skills Development Programs in Fifteen Commonwealth Countries, Ed. T. V. Rao, and C. Wright. London: Commonwealth Secretariat, 8-10. 
47. Ononaeke, C. R. (2010): Strategic Planning: A Guide (Ikeja Malthouse Pres Itd.).

48. Ogujiuba (2004): Barriers Adopting ICT and E-commerce with SMEs in Developing Countries: An Exploratory Study in Sri Lanka", CollECTeR '06, 9 December, 2006, Adelaide, [online], http://www.collecter.org/archives/2006_December/07.pdf [13 March 2008]

49. Onugu, (2005). Business Information System: A problem Solving Approach, New York, HBJ, College Publishers.

50. Paxton, J., D. Graham, and C. Thraen. (2000). Modeling Group Loan Repayment Behavior: New Insights from Burkina Faso ,Economic Development and Cultural Change.

51. Salamon. (2017). Market Failure, Voluntary Failure, and Third-Party. Journal of Voluntary Action Research .

52. Scherer, R.F., Adams, J. and Wiebe, F.A. (2019): "Role model performance effects on development of entrepreneurial career preference", Entrepreneurship Theory and Practice, 13, 53-81Stiglitz,

53. SMEDAN (2005). Small and medium enterprises development agency of Nigeria: A report presented at African entrepreneurship seminar organized in collaboration with the Scientific Committee on ntrepreneurship of the University of Essex. United Kingdom on the 5th of June

54. The Great Soviet Encyclopedia (2010:274).

55. Tijani-Alawiye B(2004). Entrepreneurship Processes and Small Business Management, Ilaro, Nigeria.

56. Udechukwu N.F. (2008). "Survey of small and medium scale industries and their potentials in Nigeria." A paper presented at CBN seminar on SMIEIS

57. Ulrich S. (2006). Stimulating Youth Entrepreneurship: Barriers and incentives to enterprise start-Ups by young people. Geneva, Switzerland: International Labour Organization.

58. United Nations. (2007, December 18). United Nations Publications. Retrieved June 21, 2009, from United Nations Web site: http://www.un.org/esa/socdev/unyin/documents/wyr07_press_release_english.pdf 4

59. Vaughan, L. Q. (2006). The Role of Information in Business Operations and Success: A Study Based on Ontario Medium-Sized Business. University of Western Ontario: Graduate School of Library and Information Science.

60. Williams, K. (2003). "Working with Angel Investors for Community Development." New York: Community Development Venture Capital Alliance.

61. Wydick, B. (1998). Can Social Cohesion be harnessed to Repair Market Failure? Evidence From Group Lending in Guatemala. The Economic Journal, 109, 463-475.

62. Yeh, Quey-Chen, and Chang, A, J-T (2007) "Proliferation of Computers among Taiwanese SMEs", International Journal of Entrepreneurship and Innovation Management, Vol. 7, No. 1,

63. Zeller, M. (2018). Determinants of Repayment Performance in Credit Groups: The Role of Program Design, Intragroup Risk Pooling, and Social Cohesion, II Economic Development And Cultural Change. 46 (3), 599-620. 